\title{
Evaluates Effect of Amino Acids, Humic Acid and Antioxidants as Foliar Application on the Biochemical Content and Productivity of Wheat Under North Sinai Soils Conditions
}

\author{
Rehab Helmy Hegab*, Hassan Abd El-atty Fawy, Ashraf Ahmed Mohamed Habib \\ Soil Fertility and Microbiology Department, Desert Research Center (DRC), Cairo, Egypt \\ Email address: \\ drrehabhh@yahoo.com(R.H.Hegab),drfawy555@hotmail.com(H. A.El-atty F.), aea_2013sc@yahoo.com(A. A. M. Habib) \\ *Corresponding author
}

\section{To cite this article:}

Rehab Helmy Hegab, HassanAbd El-atty Fawy, Ashraf Ahmed Mohamed Habib. Evaluates Effect of Amino Acids, Humic Acid and Antioxidants as Foliar Application on the Biochemical Content and Productivity of Wheat Under North Sinai Soils Conditions. American Journal of Agriculture and Forestry. Vol. 8, No. 4, 2020, pp. 167-174. doi: 10.11648/j.ajaf.20200804.19

Received: June 24, 2020; Accepted: July 13, 2020; Published: July 30, 2020

\begin{abstract}
Biostimulants are products that increase plant growth, resistance to water and abiotic stresses. it compositions, such as humic acids, amino acids, Ascorbic acids and other compounds. These substances cause changes in fundamental and structural processes to influence plant growth through enhanced tolerance to abiotic stresses and increase grain yield. The objectives of the present study were to investigate the effect of the foliar application of amino, humic and ascorbic acids with mineral fertilizers on growth, yield and chemical composition of wheat. The filed investigation was carried out at Baloza Research Station of the Desert Research Center, North Sinai, Egypt during the two successive seasons of 2019/2020. The experiment was conducted in a split plot design, with three replicates. The results obtained the yield components, total antioxidants, total phenol and nutrients concentration of wheat were increased with increasing the organic acids and antioxidants rates. The beneficial effect of treatments was arranged descending by as follows; ascorbic acid (antioxidants) $>$ amino acids $>$ humic acid $>$ control. The most effective treatment was $\mathrm{Am}_{2} \mathrm{AS}_{2}$ with hum 2 (ascorbic acid at 600 ppm) with amino and humic acids (at $600 \mathrm{ppm}$ ), which achieved $3.4 \mathrm{ton} / \mathrm{fed}$ grains of wheat. The foliar application of antioxidants recorded higher increases of yield parameters and nutrients content in straw and grains of wheat than amino acids and humic acid, while the humic acid showed the lowest effect.
\end{abstract}

Keywords: Amino Acids, Humic Acids, Antioxidants, Productivity of Wheat Crop

\section{Introduction}

The irrigation water source for wheat in the North-Sinai was the Salam canal water. The water in El Salam canal was slight salinity as $1500 \mathrm{ppm}$. The water irrigation was sufficient to complete wheat plant growth and production.

Humic molecules increased leaf water retention and the photosynthetic and antioxidant metabolism under water stress. The humic substances increased the roots density and absorbed nutrients across the plasma membranes of roots. The humic acid increased morphological criteria (plant height, leaves number, fresh and dry weights of shoots), metabolism (photosynthetic pigment, total soluble sugar, total carbohydrates, total amino acids and proline), mineral contents $(\mathrm{N}, \mathrm{P}, \mathrm{K}, \mathrm{Ca}$ and $\mathrm{Mg}$ ) and yield (grain, straw and biology) of plants, Under salt stress, the foliar application of humic substances improved the uptake of nutrients by corn plant, the previous facts according to the studies [1-3], respectively.

Amino acids functions in plant such as protein synthesis, stress resistance, effect of photosynthesis, action on the stomas, chelating effect, activators of phytohormones, pollination with fruit formation and equilibrium of soil flora, above findings according to the studies $[5,6]$.

Antioxidants security machinery protects plants against oxidative stress damages by scavenging of reactive oxygen 
species (ROS). Antioxidant machinery, such as antioxidant enzymes, ascorbic acid, carotenoids and flavonoids, the antioxidant enzyme activity protect plant cells from light, temperature and drought stress. Antioxidant as flavonoids contribute greatly to ROS-detoxification through chemical reactive for oxygen species (ROS) in plant and human cells, flavonoids have the greatly potential to effect on mitogenactivated protein kinases (MAPK) process to form protein in plants, the previous findings according to the studies [710] Effect of foliar organic acid and antioxidants application on yield parameters and nutrients contents of wheat plants. The study [11] reported that the water irrigation requirement of $(80 \%$ IR) produced high grain yield /fed and insignificantly out yielded the water irrigation requirements of $(100 \%$ IR). Rising foliar application levels of ascorbic acid significantly improved grain and straw yields/plant or/fed. The interaction between the water irrigation requirements of $(80 \%$ IR) and (300 $\mathrm{mg} / \mathrm{L}$ ) foliar application level of ascorbic acid gave the maximum values of grain, straw and protein yields/fed water use efficiency and significantly out yielded the other all interactions. The study [12] showed that the foliar application with mixture of humic and amino acids resulted the highest values of yield attributes and increased grain and straw yields, protein and carbohydrates contents in grains by $23.29,7.50,10.98$ and $78.15 \%$, respectively as compared with the control treatment. The study [13] reported that the highest values of spike length, number of grains/spike, grains weight/spike and thousand grains weight as well as grain yield were obtained by foliar application with 2 litres of humic acid/ faddan over both seasons as compared with other treatments. Higher content of carbohydrate and protein recorded with the same rate of humic acid treatment. The study [14] decided that the Maximum productivity of wheat were recorded under well watered state treated by $240 \mathrm{~kg} \mathrm{~N} \mathrm{ha}{ }^{-1}$. Nonetheless, exogenously applied ascorbic acid has superior able to produce appropriate productivity under water stress. The study [15] reported that the applied antioxidant materials and biostimulants increased the growth parameters, yield components of wheat and chemical constituents i.e, Photosynthetic pigments, Total ascorbic acid, Proline and Phenols of wheat plants grown in soil infected with F. graminearum compared with untreated plants but these values were fewer than with un infected control plants. Seaweed extracts and ascorbic acid were the most effective in increasing wheat growth, grain yield and chemical constituents under infected conditions. The study [16] decided that the foliar application twice with the combination of commercial NPK, elements, amino acids and yeast extract produced the maximum values of all studied characters in both seasons, Followed by foliar application wheat plants twice with yeast extract (YE) (100 $\mathrm{ml} /$ Liter water) in each spraying. Fertilizing with $80+45.0$ $+48.0 \mathrm{~kg} \mathrm{~N}, \mathrm{P}_{2} \mathrm{O}_{5}$ and $\mathrm{K}_{2} \mathrm{O} /$ fed gave the maximum values of all studied characters during both seasons. The study [17] stated that the obtained results revealed such significant increases in plant height, spikes number $/ \mathrm{m}^{2}$, spikelets number/spike, grains number/spike, 1000- kernel weight, grain, straw, and biological yields/fed., as well as harvest index (\%) using nano- fertilizer + amino acids during both growing seasons.

Concerning the influence of mineral fertilizers on wheat plant production, the study [18] reported that the role nutients for wheat plant increased grains weight, polyphenol and others mineral elements. The study [14] reported that the yield components of wheat plant increased with increasing rates of NPK fertilizer. The study [17] reported that the yield parameter of wheat increase with increasing rates of fertilizers and amino acids.

The objective of this study was conducted to investigate the effect of of foliar application compination of amino, humic and ascorbic acids with mineral fertilizers on nutrients content, total antioxidants, total phenols and Productivity of Wheat Crop.

\section{Materials and Methods}

The experiments carried out in Baloza station farm, at $31^{\circ}$ $3^{\prime} 0^{\prime \prime} \mathrm{N}$ and $32^{\circ} 36^{\prime} 0^{\prime \prime} \mathrm{E}$ in North Sinai soils. during two consecutive seasons of 2019 and 2020. The objective of this study was to evaluate the effect of the foliar application of amino, humic and ascorbic acids (antioxidants) at two rates (400 and $600 \mathrm{mg} \mathrm{kg-}^{1}$ ) was applied as foliar spray in two sprays and NPK and micronutrients at one rate was added to all studied treatments. The first spray was carried out after 30 days from transplanting date. Meanwhile, the other dose at the heading stage of plant growth. The eleven treatments were arranged in split plot design with three replicates, where foliar application treatments were distributed in the main plots, while rates of foliar application treatments were randomly arranged in the sub-plots. The texture farm soil was sandy, the main source of irrigation water for the wheat plant the Salam canal water. The experimental plot area was $64 \mathrm{~m}^{2}$ at North Sinai location. Sprinkler irrigation system for irrigation the grown plants was used in the experiment. Grains of wheat variety Sades 8 were sown on $10^{\text {th }}$ November in both the seasons. The soil fertilizers were added at $80 \mathrm{~N}, 40 \mathrm{P}_{2} \mathrm{O}_{5}, 60 \mathrm{~K}_{2} \mathrm{O}$ at the Table 2, Nitrogen and $\mathrm{K}$ fertilizers were split into three equal doses that were applied every 20 days after sowing for the first and second doses at 60 days while the third was added after 90 days from sowing. Organic matter was incorporated into the surface soil layer of the sandy location at $20 \mathrm{~m}^{3} / \mathrm{fed}$, soil during seedbed preparation. All phosphorus treatments amounts were added with organic matter. Fertilizer amounts, to be applied, were aimed to fulfill just above the sufficient level of each nutrient in the studied soils. Wheat was harvested during $24^{\text {th }}$ April 2019 and 2020. Soil samples were collected from the studied plots at depth $(0-30$ and $30-60 \mathrm{~cm})$ for determinations some physical and chemical properties initial analysis was shown in Table 1. The following data were recoded 
Table 1. Chemical and physical soil properties of Baloza station soil.

\begin{tabular}{|c|c|c|c|c|c|c|c|c|c|}
\hline \multirow{2}{*}{$\begin{array}{l}\text { Depth } \\
\text { Cm }\end{array}$} & \multirow{2}{*}{$\begin{array}{l}\text { pH } \\
1: 1\end{array}$} & \multirow{2}{*}{$\begin{array}{l}\text { EC } \\
\text { dS/m }\end{array}$} & OM & $\mathrm{CaCO}_{3}$ & Sand & Silt & Clay & \multirow{2}{*}{$\begin{array}{l}\text { CEC } \\
\mathrm{meq} / \mathbf{1 0 0 g}\end{array}$} & \multirow{2}{*}{ Texture } \\
\hline & & & \multicolumn{5}{|l|}{$\%$} & & \\
\hline $0-30$ & 8.23 & 0.73 & 0.83 & 2.67 & 85.3 & 7.93 & 6.77 & 4.12 & Sand \\
\hline $30-60$ & 8.51 & 0.55 & 0.74 & 2.49 & 90.51 & 4.64 & 4.85 & 2.69 & Sand \\
\hline \multicolumn{10}{|c|}{ Soluble cations and anions (me/L), amount of total antioxidants and total phenols in the studied soils } \\
\hline & $\mathrm{Na}$ & K & $\mathrm{Ca}$ & $\mathrm{Mg}$ & $\mathrm{HCO}_{3}^{-1}$ & $\mathrm{Cl}^{-1}$ & $\mathrm{SO}_{4}^{-2}$ & T. phenol & T.A.A \\
\hline $0-30$ & 2.75 & 0.84 & 1.63 & 2.11 & 1.31 & 3.33 & 2.71 & 452 & 127 \\
\hline $30-60$ & 2.13 & 0.53 & 1.23 & 1.62 & 0.71 & 2.83 & 1.97 & 417 & 118 \\
\hline \multicolumn{10}{|c|}{ Available nutrients $(\mathrm{mg} / \mathrm{kg})$ in soil } \\
\hline & $\mathrm{N}$ & $\mathrm{P}$ & $\mathrm{K}$ & $\mathrm{Fe}$ & $\mathrm{Mn}$ & $\mathrm{Zn}$ & $\mathrm{Cu}$ & & \\
\hline $0-30$ & 18.6 & 1.92 & 27 & 5.52 & 2.18 & 0.97 & 0.28 & & \\
\hline $30-60$ & 12.7 & 1.25 & 21 & 3.87 & 1.94 & 0.68 & 0.22 & & \\
\hline \multicolumn{10}{|c|}{ Some chemical properties and soluble ions of of El-Salam Canal irrigation water in Baloza Station (me/L). } \\
\hline & $\mathrm{pH}$ & EC dsm ${ }^{1}$ & $\mathrm{Na}$ & $\mathrm{K}$ & $\mathrm{Ca}$ & $\mathrm{Mg}$ & $\mathrm{HCO}_{3}^{-1}$ & $\mathrm{Cl}^{-1}$ & $\mathrm{SO}_{4}^{-2}$ \\
\hline & 7.79 & 1.76 & 11.12 & 0.71 & 3.38 & 2.41 & 1.28 & 11.13 & 5.21 \\
\hline
\end{tabular}

T.A.A $=$ Total Antioxidants $\mu \mathrm{g}$ of Ascorbic acid/ml extract, $\mathrm{T}$. phenol $=$ Total phenol $\mu \mathrm{mol}$ of Gallic acid $/ \mathrm{ml}$ extract

Table 2. Mineral fertilizers applied soil and foliar as one treatment for wheat.

\begin{tabular}{llll}
\hline Treatments & Soil feeding & & $\mathbf{K}_{\mathbf{2}} \mathbf{O}$ \\
\hline kg/fed & $\mathbf{N}$ & $\mathbf{P}_{\mathbf{2}} \mathbf{O}_{\mathbf{5}}$ & 60 \\
\hline NPK & 80 & 40 & $\mathrm{~K}$ \\
Foliar & Foliar feeding ppm /600L/fed & & 799 \\
Stages & $\mathrm{N}$ & $\mathrm{P}$ & 938 \\
Stage 1 & 1265 & 435 & 1007 \\
Stage 2 & 1098 & 507 & 2744 \\
Stage 3 & 927 & 623 & 1565 \\
Sum & 3290 & & \\
\hline
\end{tabular}

Table 3. Treatments of amino, humic, and ascorbic acids for wheat.

\begin{tabular}{|c|c|}
\hline \multicolumn{2}{|c|}{ Micronutrients treatment $\left(\mathrm{mg} \mathrm{kg}^{-1}\right)$} \\
\hline Micro & $300 \mathrm{ppm}$ of $\mathrm{Fe}, \mathrm{Mn}$ and $\mathrm{Zn}$ while $50 \mathrm{ppm}$ of B (as Boric acid) \\
\hline \multicolumn{2}{|c|}{ Organic acid and antioxidant rates } \\
\hline Humic acid & 400 and $600 \mathrm{mg} \mathrm{kg}^{-1}$ (9.32 and $13.98 \mathrm{~g}$ of K-humate $86 \% / 20 \mathrm{~L}$ respectively) \\
\hline Amino acids & 400 and $600 \mathrm{mg} \mathrm{kg}^{-1}$ (40 and $60 \mathrm{ml}$ of amino acids $20 \% / 20 \mathrm{~L}$ respectively) \\
\hline Ascorbic acid & 400 and $600 \mathrm{mg} \mathrm{kg}^{-1}$ ( 8 and $12 \mathrm{~g}$ of ascorbic acid $100 \% / 20 \mathrm{~L}$ respectively) \\
\hline
\end{tabular}

The requirements of nutrients for wheat plant during the stages growth were different about the wheat plant requirements. Foliar applied amount of mineral fertilizers to the wheat plant were applied at one rate (control) through the two seasons is described at Table 3. The foliar mineral fertilizers, amino acids $20 \%(2.9 \% \mathrm{Fe}, 1.4 \% \mathrm{Zn}$ and $0.7 \%$ $\mathrm{Mn}), \mathrm{K}$-humate $\left(86 \%\right.$ humic acid and $12 \% \mathrm{~K}_{2} \mathrm{O}$ ) and ascorbic acid $(100 \%)$ application regime as following after soil fertilizers application by one week. The following data were recoded

\subsection{Growth and Yield Parameters}

At maturity, $1 \mathrm{~m}^{2}$ in the center of each experimental plot was chosen to be harvested for the estimation of biological parameters (biological yields, dry weights of straw, grain and Spikes, Number. Spikes and 1000 grain weight).

\subsection{Determination of Macro and Micronutrients in Straw and Grain of Plant}

$\mathrm{N}, \mathrm{P}$ and $\mathrm{K}$ in both grain and shoots were determined in acid digested solution, which was prepared according to [19].

\subsection{Determination of Total Antioxidant Activity and Total Phenolic Compounds in Dry Herb of Plant}

\subsubsection{Plant Material Extraction}

For extraction of antioxidant and phenolic Acids compounds, the leaves of wheat plants were air dried at room temperature for $48 \mathrm{~h}$. Air dried ground leaf tissue $(0.5 \mathrm{~g})$ was soaked in $50 \%$ methanol $(50 \mathrm{~mL})$. Then; the extract was transferred to $100 \mathrm{ml}$ volumetric flask and made up the volume with $50 \%$ Methanol. The mixture was shaken in the orbital shaker for $20 \mathrm{~min}$ and centrifuged then filtered by muslin cloth. After that, the filtrate was used for the following experiments [20].

\subsubsection{Measurement of total Antioxidant Activity}

The extract $(0.1 \mathrm{ml})$ was mixed with $3 \mathrm{ml}$ of reagent solution (0.6 M sulphuric acid, $28 \mathrm{mM}$ sodium phosphate and $4 \mathrm{mM}$ ammonium molybdate). The tubes were incubated at $95^{\circ} \mathrm{C}$ for $90 \mathrm{~min}$. The mixture was cooled to room temperature, and then the absorbance of the solution was measured at $695 \mathrm{~nm}$ against blank. The total antioxidant activity was expressed as ascorbic acid equivalents in 
milligrams per gram of the extract [21].

\subsubsection{Measurement of Total Phenol Compounds}

Total phenolic constituents of plant extracts were performed employing the literature methods involving FolinCiocalteu reagent and gallic acid as standard [22]. Extract solution $(0.1 \mathrm{ml})$ containing $1000 \mathrm{ug}$ extract was taken in a volumetric flask, $46 \mathrm{ml}$ distilled water and $1 \mathrm{ml}$ FolinCiocalteu reagent were added and flask was shaken thoroughly. After $3 \mathrm{~min}, 3 \mathrm{ml}$ of solution $2 \% \mathrm{Na}_{2} \mathrm{CO}_{3}$ was added and the mixture was allowed to stand for $2 \mathrm{~h}$ with intermittent shaking. Absorbance was measured at $760 \mathrm{~nm}$. The same procedure was repeated to all standard gallic acid solutions $\left(0-1000 \mathrm{mg}, 0.1 \mathrm{ml}^{-1}\right)$ and standard curve was obtained.

\subsection{Soil Properties of the Experiment}

\subsubsection{Mechanical analysis}

Mechanical analysis was determined according to the method described by [23].

\subsubsection{Some Chemical Properties}

Soil hydrogen potential $(\mathrm{pH})$ was determined electrometrically in soil suspension 1:5 using bench Beckman Glass Electrode pH-Meter, total soluble salts (EC) were determined in soil suspension 1:1 were determined according to the study [24]

\subsubsection{Determination of Available Macro and Micronutrients in Soil}

Available nitrogen in soil samples was extracted by $2 \mathrm{M}$ potassium chloride solution and determined according to the study [25]. Available potassium, phosphorous and micronutrients were extracted by DTPA + ammonium carbonate solution and measurement according to the method described by the study [26].

\subsection{Statistical Analysis}

Data of the present investigation were statistically analyzed and the differences between the means of the treatments were considered significant when they were more than the least significant differences (L.S.D) at the 5\% level by using computer program of Statistix version 9 [27].

\section{Results and Discussion}

\subsection{Effect of Organic Acids and Antioxidants on Yield of Wheat}

The available nutrients in the Sinai soil are present at (Table 1). Some of available nutrients were not sufficient for growth requirements of wheat plant. Therefore, a foliar application of mineral fertilization and some amendments to complete the plant growth and production especially when rain season end become necessary and it must be taken in the consideration.

Table 4. Effect of foliar amino, humic and ascorbic acids applied on the yield components of wheat (average of the two seasons).

\begin{tabular}{|c|c|c|c|c|c|c|}
\hline \multirow{2}{*}{ Treatments } & Biological yield & Straw & Grains & Weight 1000 & Weight. Spikes & Number. Spikes \\
\hline & \multicolumn{3}{|l|}{ ton/fed } & grain (g) & $/ \mathbf{m}^{2} \mathbf{k g}$ & $/ \mathbf{m}^{2}$ \\
\hline Hum1 & 5.47 & 3.94 & 1.53 & 35 & 0.64 & 161 \\
\hline Am1 & 6.41 & 4.6 & 1.81 & 37 & 0.68 & 167 \\
\hline Hum2 & 6.6 & 4.75 & 1.86 & 39 & 0.69 & 168 \\
\hline $\mathrm{Am} 2$ & 7.05 & 5.15 & 1.9 & 40 & 0.69 & 173 \\
\hline AS2 & 7.53 & 4.67 & 2.86 & 41 & 0.73 & 176 \\
\hline Am2+ Hum2 & 7.78 & 4.82 & 2.96 & 43 & 0.71 & 174 \\
\hline Am1+Hum1+AS1 & 7.92 & 4.91 & 3.01 & 46 & 0.75 & 186 \\
\hline Am2+Hum2+AS2 & 8.6 & 5.2 & 3.4 & 51 & 0.78 & 190 \\
\hline farmer & 5.10 & 3.16 & 1.94 & 31 & 0.62 & 156 \\
\hline LSD $_{0.05}$ Treatmants & 0.09 & 0.05 & 0.05 & 0.46 & 0.006 & 1.35 \\
\hline LSD $_{0.05}$ Rates & 0.11 & 0.06 & 0.06 & 0.56 & 0.007 & 1.66 \\
\hline LSD $_{0.05} 2$ factors & 0.15 & 0.09 & 0.08 & 0.79 & 0.010 & 2.34 \\
\hline
\end{tabular}

$\mathrm{Am}=$ amino acids, $\mathrm{AS}=$ ascorbic acid, Hum=Humic acid, $1=400 \mathrm{ppm}, 2=600 \mathrm{ppm}$

The NPK and micronutrients fertilizers applied at one rate for all studied treatments (Tables 2, 3) which were suitable nutrients to approach the sufficient levels of nutrients for obtain a good growth and highest grains production of wheat plant.

Data in Table 4 and (Figure 1). showed that the yield components of wheat increased with increasing the applied rates of foliar humic, amino and ascorbic acids. In this respect, the antioxidant (ascorbic acid) treatment induced the higher yield of wheat plant than the amino acid, while the humic acid occurred the lowest effect. Ascorbic acid treatment recorded increases over farmer treatment by 38.8 , 46.2 and $24.4 \%$ for straw, grains and 1000 grains weight of wheat respectively while the amino acids treatment achieved
44.5, 18.9 and $22.5 \%$, and the humic acid 39.8, 17.2 and $20.5 \%$ in comparison with the farmer treatment. We found in this result, while the amino acids treatment superior in the straw while ascorbic acid treatment was superior in the grains.

The interactions between the amino acids and humic acid increased impact on the yield parameters of wheat plant by increasing organic acids rates. The treatment $(600 \mathrm{mg} / \mathrm{kg}$ of amino acid $+600 \mathrm{mg} / \mathrm{kg}$ of humic acid) induced a higher increases of grains yield than 400 amino acid $+400 \mathrm{mg} / \mathrm{kg}$ of humic acid by $13.9,14.2$ and $7.0 \%$ for straw, grains and 1000 grains weight of wheat, respectively.

The interactions between amino, humic and ascorbic acids 
achieved the highest increases for grains yield components of wheat when compared with other studied treatments. The most affect treatment $\left(\mathrm{Am}_{2} \mathrm{AS}_{2} \mathrm{Hum}_{2}\right)$ achieved 5.2 and 3.4 ton/fed and $51 \mathrm{~g}$ for straw, grains and 1000 grains weight of wheat, respectively,

The previous results indicate that the antioxidants were the most beneficial effective on the production of wheat plant. Followed by amino acids and humic acid, this due to the antioxidants have an important role to increase the ability of olive and figure trees to resistance drought conditions and increase of proline levels in the plant, which increase the plant ability to continue the natural growth under conditions of Paloza station farm in North Sinai soils. These facts has been reported by $[1,2,3,18]$. The importance of the role of humic and amino acids in the plant stated by the studies $[4,5,6,28]$, while the plant's ability to tolerate drought stress conditions and role of antioxidants decided by the studies [7-10].

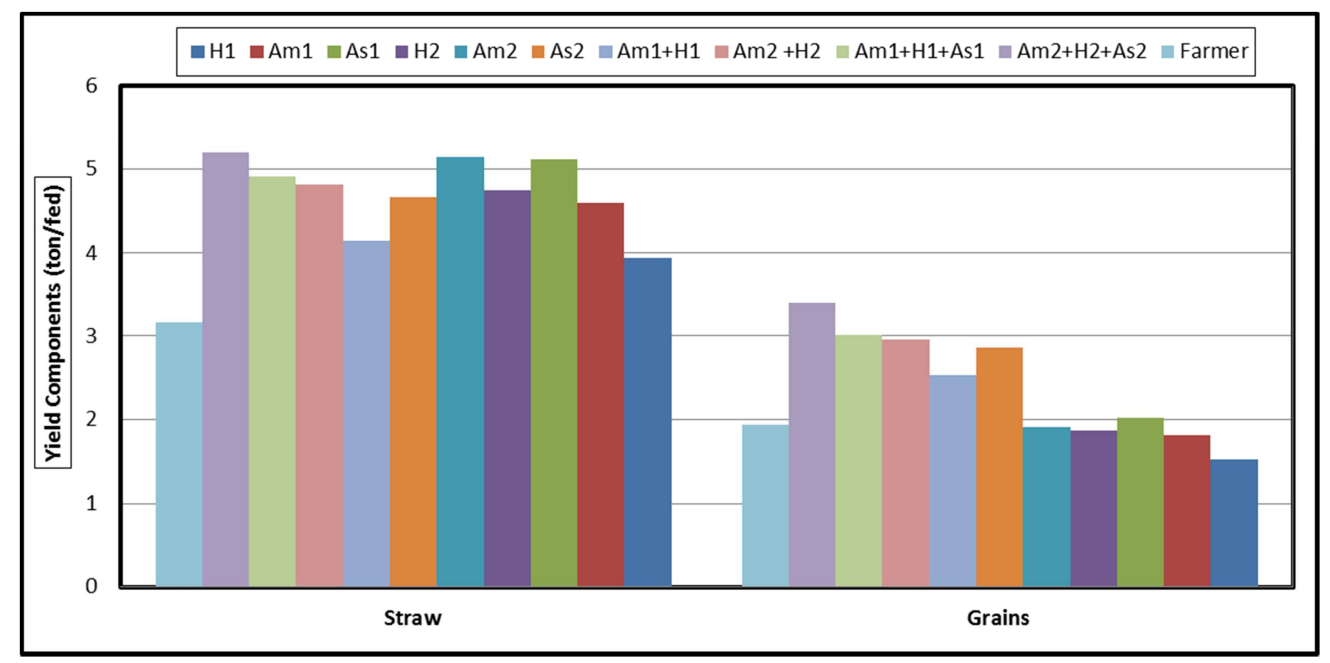

Figure 1. Effect of foliar amino, humic and ascorbic acids applied on dry weights of straw and grain of wheat.

\subsection{Effect of Organic Acids and Antioxidants on Nutrients Contents of Wheat}

The nutrients contents in leaves and fruits of wheat increased with increasing the organic acids and antioxidant rates. The superior treatment $\left(\mathrm{Am}_{2} \mathrm{AS}_{2} \mathrm{Hu}_{2}\right)$ achieved highest nutrients contents in straw and grains of wheat when compared with other studied treatments.

Table 5. Effect of foliar amino, humic and ascorbic acids applications on macronutrients contents in straw and grains of wheat (average of the two seasons).

\begin{tabular}{|c|c|c|c|c|c|c|}
\hline \multirow{2}{*}{ Treatments } & \multicolumn{3}{|c|}{ Macronutrients in straw } & \multicolumn{3}{|c|}{ Macronutrients in Grains } \\
\hline & $\mathbf{N \%}$ & $\mathbf{P \%}$ & $\mathbf{K} \%$ & $\mathbf{N \%}$ & $\mathbf{P \%}$ & $\mathbf{K} \%$ \\
\hline Hum1 & 0.47 & 0.079 & 1.46 & 0.58 & 0.183 & 0.472 \\
\hline Am1 & 0.57 & 0.091 & 1.19 & 0.67 & 0.199 & 0.449 \\
\hline AS1 & 0.44 & 0.077 & 1.11 & 0.57 & 0.176 & 0.416 \\
\hline Hum2 & 0.57 & 0.114 & 1.91 & 1.17 & 0.245 & 0.589 \\
\hline $\mathrm{Am} 2$ & 0.60 & 0.125 & 1.39 & 1.26 & 0.278 & 0.496 \\
\hline AS2 & 0.56 & 0.105 & 1.28 & 1.12 & 0.224 & 0.488 \\
\hline Am2+ Hum2 & 0.78 & 0.121 & 1.42 & 1.31 & 0.293 & 0.565 \\
\hline Am1+Hum1+AS1 & 0.64 & 0.126 & 1.49 & 1.16 & 0.283 & 0.486 \\
\hline Am2+Hum2+AS2 & 0.79 & 0.140 & 1.68 & 1.22 & 0.315 & 0.576 \\
\hline farmer & 0.43 & 0.087 & 1.12 & 0.52 & 0.184 & 0.367 \\
\hline LSD $_{0.05}$ Treatmants & 0.009 & 0.0016 & 0.017 & 0.022 & 0.0038 & 0.0053 \\
\hline LSD $_{0.05}$ Rates & 0.011 & 0.0020 & 0.021 & 0.027 & 0.0046 & 0.0065 \\
\hline $\operatorname{LSD}_{0.05} 2$ factors & 0.016 & 0.0028 & 0.029 & 0.039 & 0.0066 & 0.0092 \\
\hline
\end{tabular}

$\mathrm{Am}=$ amino acids, $\mathrm{AS}=$ ascorbic acid, Hum=Humic acid, $1=400 \mathrm{ppm}, 2=600 \mathrm{ppm}$

Data at Tables 5, 6 show that antioxidants treatments showed that the highest effect on $\mathrm{P}$ and micronutrients contents. Amino acids achieved the highest effect on $\mathrm{N}$ contents, while humic acid was the highest for $\mathrm{K}$ contents in straw and grains of wheat. The ascorbic acid increased N, P, $\mathrm{K}, \mathrm{Fe}, \mathrm{Mn}, \mathrm{Zn}$ and $\mathrm{Cu}$ by $23.2,17.1,12.5,49.2,44.5,28.8$ and $59 \%$ in wheat straw respectively, over farmer treatment, while that they were $53.6,17.9,24.8,33.1,33.3,37.3$ and
$40.8 \%$ for wheat grains. The amino acid treatment recorded about 28.3, 30.4, 19.4, 52, 48.2, 29 and $61.3 \%$ for N, P, K, $\mathrm{Fe}, \mathrm{Mn}, \mathrm{Zn}$ and $\mathrm{Cu}$ of wheat straw compared to farmer treatment respectively. While that they were 58.7, 33.8, 26, $60,25.5,39.2$ and $41.9 \%$ for wheat grains. The humic acid achieved increase over farmer treatment by about 24.6, 23.7, 41.4, 53.5, 51, 33.3 and $62.9 \%$ for N, P, K, Fe, Mn, Zn and $\mathrm{Cu}$ of wheat straw respectively, while that they were 55.6, 
$24.9,37.7,63.5,32,41.7$ and $49.7 \%$ for grains of wheat plant at (Tables 5,6$)$. The previous results agree with that obtained

by the studies [11-17].

Table 6. Effect of foliar amino, humic and ascorbic acids applications on micronutrients contents in straw and grains of wheat (average of the two seasons).

\begin{tabular}{|c|c|c|c|c|c|c|c|c|}
\hline \multirow{2}{*}{ Treatments } & \multicolumn{4}{|c|}{ Micronutrients in straw ppm } & \multicolumn{4}{|c|}{ Micronutrients in Grains ppm } \\
\hline & $\mathbf{F e}$ & Mn & Zn & $\mathbf{C u}$ & $\mathbf{F e}$ & Mn & Zn & $\mathbf{C u}$ \\
\hline Hum1 & 18.80 & 10.16 & 4.91 & 2.68 & 10.94 & 5.83 & 3.90 & 1.51 \\
\hline Aml & 17.59 & 9.48 & 4.66 & 2.59 & 10.55 & 5.52 & 3.52 & 1.38 \\
\hline AS1 & 16.46 & 8.81 & 4.17 & 2.48 & 10.00 & 5.24 & 3.31 & 1.21 \\
\hline Hum2 & 22.64 & 11.17 & 5.86 & 2.83 & 19.62 & 6.71 & 4.99 & 1.85 \\
\hline $\mathrm{Am} 2$ & 21.96 & 10.57 & 5.51 & 2.71 & 17.90 & 6.12 & 4.79 & 1.60 \\
\hline AS2 & 20.74 & 9.85 & 5.49 & 2.56 & 10.71 & 6.84 & 4.64 & 1.57 \\
\hline Am2+ Hum2 & 21.38 & 10.69 & 5.39 & 2.81 & 18.45 & 5.18 & 4.68 & 1.85 \\
\hline Am1+Hum1+AS1 & 18.50 & 9.58 & 4.65 & 2.13 & 11.74 & 4.40 & 3.92 & 1.67 \\
\hline Am2+Hum2+AS2 & 26.06 & 12.58 & 6.18 & 2.92 & 19.11 & 6.85 & 4.96 & 1.92 \\
\hline farmer & 10.53 & 5.47 & 3.91 & 1.05 & 7.16 & 4.56 & 2.91 & 0.93 \\
\hline LSD $_{0.05}$ Treatmants & 0.28 & 0.13 & 0.06 & 0.03 & 0.30 & 0.12 & 0.05 & 0.02 \\
\hline LSD $_{0.05}$ Rates & 0.35 & 0.15 & 0.07 & 0.04 & 0.37 & 0.12 & 0.07 & 0.03 \\
\hline LSD $_{0.05} 2$ factors & 0.49 & 0.22 & 0.10 & 0.06 & 0.52 & 0.12 & 0.09 & 0.04 \\
\hline
\end{tabular}

$\mathrm{Am}=$ amino acids, $\mathrm{AS}=$ ascorbic acid, Hum=Humic acid, $1=400 \mathrm{ppm}, 2=600 \mathrm{ppm}$

The obtained data in tables 5, 6 indicated to the impact of interactions between antioxidants and humic acid and amino acids, The results confirm the existence higher relationship between the $\mathrm{N}$ content in plant and amino acids application as well as the $\mathrm{N}$ content increased with increasing amino acids application rates. This may be due to that the amino acids contain an amin groups $\left(\mathrm{NH}_{2}\right)$ which containing nitrogen.

The $\mathrm{K}$ content in the plant increased with humic acid application rates. Finally, P content in the plant increased with addition of antioxidants this was probably due to participate in the biological processes in the plant. Also the presence of micronutrients increased the enzyme activity which produces the antioxidants; this was leading to increase the antioxidants within the plant, which reflects positively increases the plant's ability to with stand drought stress and salinity. In addition the antioxidants improve the plant growth and raise grains productivity and quality of wheat under conditions of Baloza station soils in the North Sinai. Therefore, the best treatment $\left(\mathrm{Am}_{2} \mathrm{AS}_{2} \mathrm{Hum}_{2}\right)$ was a trilateral interaction between study factors, which achieved the highest yield components and nutrients contents in the straw and grains of wheat plant. This may be due to the role of the studied acids (ascorbic acid, and amino acids humic acid) in plant such as the nutrition, regulation plant growth, active participation in the vital processes within the plant, which increased the plant's ability to resist stress caused by drought or salinity conditions, improved the plant growth, increased the productivity and the quality of the grains of wheat plant. These findings were reported by the studies $[2,18]$ for humic acid, $[5,6]$ for amino acids and $[9,10]$ for ascorbic acid.

Regarded to the influence of the studied treatments, the results has confirmed the beneficial effect of antioxidants in a positive impact on productivity and nutrients concentrations in the straw and grains of wheat plant. Antioxidants appeared the highest effect followed by amino acids then humic acid showed the lowest effect. The amino acids effect increased yield components and the nutrients concentrations in the straw and grains of wheat with increasing foliar application rates, and it has a higher effect than humic acid. This result may be due to the humic and amino acids functions in plant. The previous results agree with those obtained by the studies [11-17].

\subsection{Effect of Amino, Humic and Ascorbic Acids on Biochemical of Wheat Plant}

Data in Table 7 and figure 2 explained that the foliar application of amino, humic and ascorbic acids with sufficient mineral fertilization increased total phenols and total antioxidant in straw and grains of wheat compared with the farmer treatment. The total phenols and total antioxidant contents in straw and grains of wheat plant increased with increasing amino, humic and ascorbic acids application rates.

Table 7. Effect of amino, humic and ascorbic acids on biochemical in the wheat.

\begin{tabular}{|c|c|c|c|c|}
\hline \multirow{4}{*}{ Treatments } & \multicolumn{4}{|c|}{ Wheat plant } \\
\hline & \multicolumn{2}{|c|}{ T. Antioxidants } & \multicolumn{2}{|c|}{ T. phenols } \\
\hline & \multicolumn{2}{|c|}{$\mu \mathrm{g} \mathrm{ASA} / \mathrm{ml}$} & \multicolumn{2}{|c|}{$\mu \mathrm{mol}$ GalA/ml } \\
\hline & straw & grains & Straw & grains \\
\hline Hum1 & 248 & 158 & 467 & 293 \\
\hline Aml & 312 & 179 & 612 & 382 \\
\hline AS1 & 643 & 238 & 1177 & 825 \\
\hline Hum2 & 275 & 171 & 552 & 369 \\
\hline $\mathrm{Am} 2$ & 423 & 205 & 686 & 475 \\
\hline AS2 & 731 & 251 & 1306 & 987 \\
\hline Am1+ Hum1 & 255 & 167 & 479 & 326 \\
\hline Am2+ Hum2 & 449 & 213 & 692 & 482 \\
\hline Am1+Hum1+AS1 & 697 & 294 & 1256 & 912 \\
\hline Am2+Hum2+AS2 & 759 & 371 & 1373 & 1028 \\
\hline farmer & 212 & 122 & 369 & 253 \\
\hline LSD $_{0.05}$ Treatmants & 14 & 4.87 & 25.5 & 19.9 \\
\hline LSD $_{0.05}$ Rates & 18 & 5.96 & 31.3 & 24.4 \\
\hline $\operatorname{LSD}_{0.05} 2$ factors & 25 & 8.43 & 44.2 & 34.5 \\
\hline
\end{tabular}

$\mu \mathrm{g} \mathrm{ASA} / \mathrm{ml}=\mu \mathrm{g}$ of Ascorbic acid $/ \mathrm{ml}$ extract, $\mu \mathrm{mol} \mathrm{GalA} / \mathrm{ml}=\mu \mathrm{mol}$ of Gallic $\mathrm{acid} / \mathrm{ml}$ extract, $\mathrm{T}=$ Total, $\mathrm{Am}=$ amino acids, $\mathrm{AS}=$ ascorbic acid, Hum=Humic acid, $1=400 \mathrm{ppm}, 2=600 \mathrm{ppm}$ 
Moreover, ascorbic acid treatments showed higher effects for total phenols, total antioxidant contents in straw and grains of wheat plant than amino and humic acids treatments. In grains of total antioxidant and total phenols increased with increasing application rates of studied factors (ascorbic, amino and humic acids). The most effective treatment $\left(\mathrm{Am}_{2}\right.$ $\mathrm{AS}_{2} \mathrm{Hum}_{2}$ ) recorded the highest content of biochemical in straw and grains of wheat. [11-17].
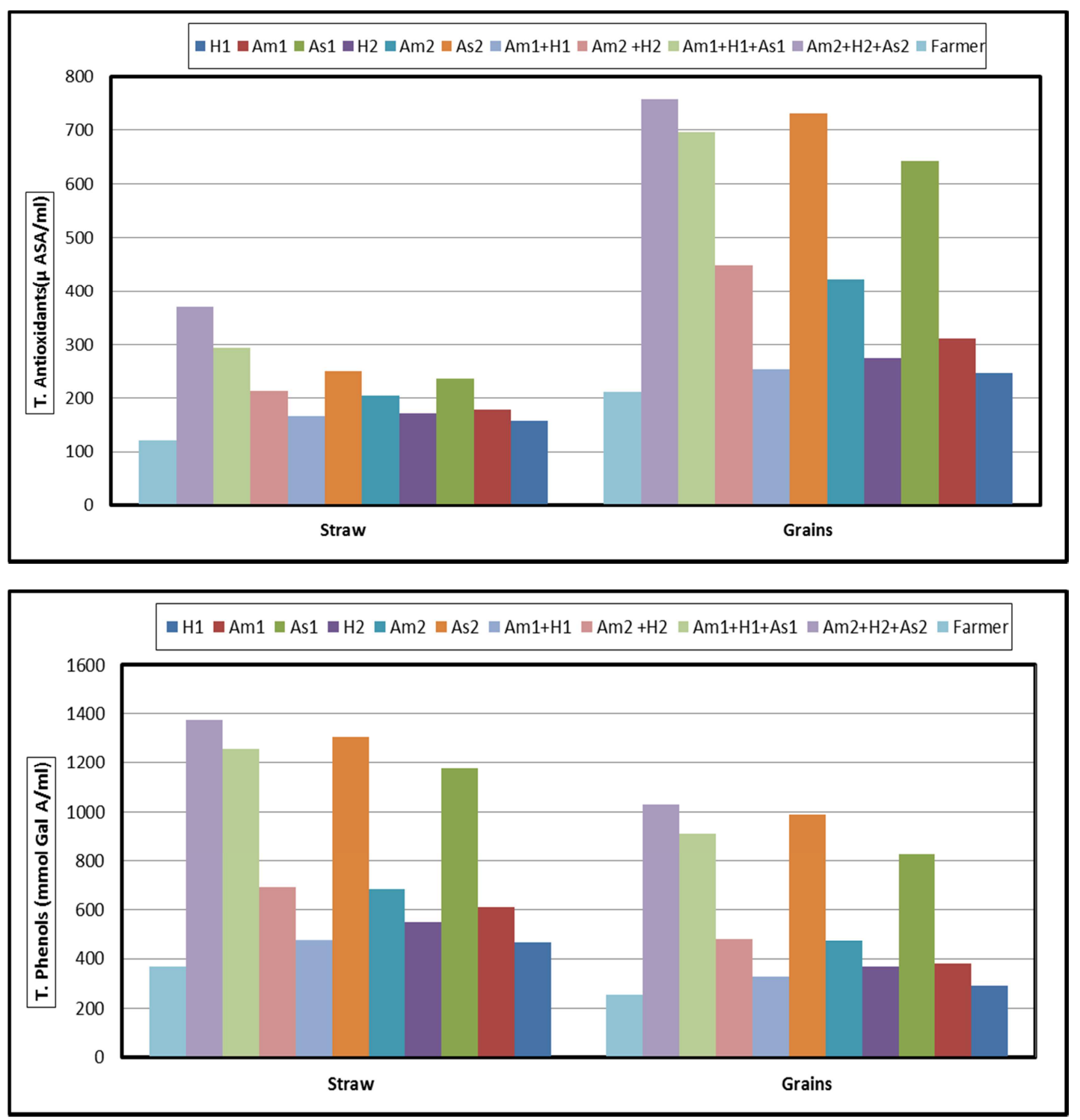

Figure 2. Effect of foliar amino, humic and ascorbic acids applied on T. Antioxidants and T. phenols of wheat.

\section{Conclusion}

Under conditions of Baloza station soils in the North Sinai, the foliar application of amino, humic and ascorbic acids (antioxidants) with NPK and micronutrients at one rate was added to all studied treatments (Table 2), the yield components, total antioxidants, total phenol and nutrients concentration of wheat were increased with increasing the organic acids and antioxidants rates. The beneficial effect of treatments was arranged descending by as follows; ascorbic acid (antioxidants) $>$ amino acids $>$ humic acid $>$ control. The most effective treatment was $\mathrm{Am}_{2} \quad \mathrm{AS}_{2}$ with hum (ascorbic acid at $600 \mathrm{ppm}$ ) with amino and humic acids (at $600 \mathrm{ppm}$ ), which achieved 3.4 ton/fed grains of wheat. The foliar application of antioxidants recorded higher increases of yield parameters and nutrients content in straw and grains of wheat than amino acids and humic acid, while the humic acid showed the lowest effect.

\section{References}

[1] Fahramand, M.; Moradi, H, M.; Noori.; Sobhkhizi, A.; Adibian, M.; abdollahi, V. and K. Rigi (2014). Influence of humic acid on increase yield of plants and soil properties. International Journal of Farming and Allied Sciences, 3 (3): 339-341.

[2] Canellas, L. P. and F. L Olivares (2014). Physiological responses to humic substances as plant growth promoter. Canellas and Olivares Chemical and Biological Technologies in Agriculture, 1 (3): 1-11. 
[3] Khaled, H. and H. A. Fawy (2011). Effect of different levels of humic acids on the nutrient content, plant growth, and soil properties under conditions of salinity. Soil and Water Res., 6 (1): 21-29.

[4] Ortiz-Lopez, A.; Chang, H. C. and D. R. Bush (2000). Amino acid transporters in plants. Biochimica et Biophysica Acta 1465: 275-280.

[5] Abd El-Samad, H. M.; Shaddad, M. A. K. and N. Barakat (2010). The role of amino acids in improvement in salt tolerance of crop plants. Journal of Stress Physiology \& Biochemistry, 6 (3): 25-37.

[6] Gioseffi, E.; Neergaard, A. d. and J. K. Schjoerring (2012). Interactions between uptake of amino acids and inorganic nitrogen in wheat plants. Biogeosciences, 9: 1509-1518.

[7] Hamid, A. A.; Aiyelaagbe, O. O.; Usman, L. A.; Ameen, O. M. and A. Lawal (2010). Antioxidants: Its medicinal and pharmacological Applications. African Journal of Pure and Applied Chemistry, 4 (8): 142-151.

[8] Gill, S. S. and N. Tuteja (2010). Reactive oxygen species and antioxidant machinery in abiotic stress tolerance in crop plants. Plant Physiology and Biochemistry, 48: 909-930.

[9] Agatia, G.; Azzarellob, E.; Pollastri, S. and M. Tattini (2012). Flavonoids as antioxidants in plants: Location and functional significance. Plant Science, 196: 67-76.

[10] Brunetti, C.; Ferdinando, M. D.; Fini, A.; Pollastri, S. and M. Tattini (2013). Flavonoids as antioxidants and developmental regulators: relative significance in plants and humans. Int. J. Mol. Sci., 14: 3540-3555.

[11] Bakry, A. B, Abdelraouf, R. E and Ahmed (2013). Effect of drought stress and ascorbic acid foliar application on productivity and irrigation water use efficiency of wheat under newly reclaimed sandy soil. Elixir Agri., 57A: 14398-14403.

[12] Kandil A. A.; Sharief A. E. M.; Seadh S. E. and Altai D. S. K (2016). Role of humic acid and amino acids in limiting loss of nitrogen fertilizer and increasing productivity of some wheat cultivars grown under newly reclaimed sandy soil. International Journal of Advanced Research in Biological Sciences, Int. J. Adv. Res. Biol. Sci., 3 (4): 123-136.

[13] Manal, F. M.; Thalooth, A. T; Amal, G. Ahmed, Magda H. Mohamed and T. A. Elewa (2016). Evaluation of the effect of chemical fertilizer and humic Acid on yield and yield components of wheat plants (Triticum aestivum) grown under newly reclaimed sandy soil. International Journal of ChemTech Research, 9 (8): 154-161.

[14] Hafez, E. M. and H. S. Gharib (2016). Effect of exogenous application of ascorbic acid on physiological and biochemical characteristics of wheat under water stress. International Journal of Plant Production, 10 (4): 579-596.
[15] Sakr, M. T.; El-Sarkassy, N. M. and M. P. Fuller (2017). Exogenously applied antioxidants and biostimulants counteract the adverse effect of biotic stress in wheat plant. Agri. Res. \& Tech.: 12 (4): 0090-0096.

[16] Seadh, S. E.; W. A. E. Abido and Samar E. A. Ghazy (2017). Impact of Foliar and NPK Fertilization Treatments on Bread Wheat Productivity and Quality. J. Plant Production, Mansoura Univ., 8 (1): 65-69.

[17] Kandil, E. E. and Eman A. O. Marie (2017). Response of Some Wheat Cultivars to Nano- Mineral Fertilizers and Amino Acids Foliar Application. ALEXANDRIA SCIENCE EXCHANGE JOURNAL, VOL. 38, No 1: 53-67.

[18] El-Bassiouny, H. S. M.; Bakry, B. A.; Attia, A. A. and M. M. Abd Allah (2014). Physiological role of humic acid and nicotinamide on improving plant growth, yield, and mineral nutrient of wheat (Triticum durum) grown under newly reclaimed sandy soil. Agricultural Sciences, 5, 687-700.

[19] Cottenie, A.; Verlso, M.; Kilkens, L.; Velghe, G. and Camerlynck, R. (1982). Chemical Analysis of Plants and Soils. Lab. Agroch. State Univ. Gent, Belgium.

[20] Rimmer; Smith (2009). Antioxidants in soil organic matter and in associated plant materials. European J. of Soil Sci. 60 (2): $170-175$.

[21] Prieto, P.; M. Pineda and V. Aiguel (1999). Spectrophotometer Quantization of antioxidant capacity through the formation of Phosphomolybdenum Complex: Specific application to the determination of vitamin E. Anal. Biochem., 269: 337-341.

[22] Slinkard, K and V. L. Singleton (1977). Total phenol analyses: automation and comparison with manual methods. Am. J. Enol. Viticult. 28: 49-55.

[23] Piper, C. S. (1950). Soil and plant analysis, Waite Agric. Res. Inst., Adelaide, S. A., Australia.

[24] Jackson, M. L. (1973). Soil Chemical Analysis, Prentice hall, England, U. K.

[25] Dhank, W. C. and Johnson G. V. (1990). Testing soils for available nitrogen. In: soil testing and plant analysis, 3rd ed., SSSA book series No. 3, R. L. Westerman (ed.). Madison, WI: Soil Sci. Soc. of Am. J., 127-139.

[26] Soltanpour, P. N. (1985). Use of ammonium bicarbonateDTPA soil test to evaluate elemental availability and toxicity. Commun. Soil Sci. Plant Anal., 16 (3): 323-338.

[27] Analytical software, (2008). Statistix Version 9, Analytical Software, Tallahassee, Florida, USA.

[28] El-Sayed, Soad Y. S. and Rehab H. Hagab (2020). Effect of Organic Acids and Plant Growth Promoting Rhizobacteria (PGPR) on Biochemical Content and Productivity of Wheat under Saline Soil Conditions. Middle East Journal of Agriculture Research, 9 (2): 227-242. 